\title{
EATING BEHAVIOUR AND OBESITY: GENDER-AGE FEATURES
}

D0I: 10.36740/WLek202105112

\author{
Liudmyla S. Kiro ${ }^{1}$, Maksym Y. Zak ${ }^{1}$, Oleh V. Chernyshov ${ }^{1}$, Alla E. Nikolenko ${ }^{2}$, Nataliia O. Iakovenko' \\ 1 MEDICAL INSTITUTE OF THE PETRO MOHYLA BLACK SEA NATIONAL UNIVERSITY, MYKOLAIV, UKRAINE \\ 2STATE INSTITUTION «DNIPROPETROVSK MEDICAL ACADEMY OF THE MINISTRY OF HEALTH OF UKRAINE», DNIPRO, UKRAINE
}

\begin{abstract}
The aim: Identify the types of eating behaviour in overweight and obesity depending on gender and age.

Materials and methods: A survey of 210 people (men -105, women -105) was conducted. The age of women ranged from 19 to 60 years, the average age was $41.5 \pm 11.2$ years. The age of men ranged from 22 to 60 years, the average age was $42.3 \pm 12.3$ years.

The examined patients were divided into two clinical groups: group I - 70 people (women - 35, men - 35) with overweight. BMl of persons of the I group from $25.8 \mathrm{~kg} / \mathrm{m}^{2}$ to $29,3 \mathrm{~kg} / \mathrm{m} 2^{\left(B M T_{\text {mid" }}\right.}=27,5 \pm 1,31 \mathrm{~kg} / \mathrm{m}^{2}$ ); Group II - 72 people with 1st degree obesity (women -36, men - 36). Evaluation of eating disorders was carried out using the DEBQ questionnaire (Nederland) adapted to the purpose of the study.

Results: In patients of groups I and II healthy type of eating behaviour was recorded less often than in control groups, 5.38 times $(D=13.561, p=0.002<0.05)$ and 10.45 times $(D=21.043, p=0.022<0.05)$, respectively. In group I, the restrictive type of $E B$ among women occurred 1.7 times more often than in men $(D=0.852, p=0.001)$. In group II, the restrictive type of EB among women was observed 1.3 times more often than in men $(D=0.382, p=0.005)$.

Conclusions: Restrictive eating behaviour disorders are one of the leading factors in the development of overweight and obesity. Correction of eating disorders in obese people must be carried out taking into account the gender and age characteristics of the patient, to obtain positive results for a shorter course of treatment.
\end{abstract}

KEY WORDS: obesity, overweight, eating behaviour, body mass index

Wiad Lek. 2021;74(5):1114-1119

\section{INTRODUCTION}

Overweight and obesity are one of the most pressing medical and social problems of our time, which occurs at any age, it affects about $30 \%$ of endocrinological patients. The social significance of the problem of obesity is determined by the threat of disability of young patients and the reduction of overall life expectancy due to the frequent development of severe comorbidities. Eating Disorders (ED) - this is the name of eating disorders, are the leading factors in the development of overweight and obesity. According to scientific literature, at least 30 million people of all ages and genders in the world suffer from ED [1].

Eating behaviour is a set of eating habits, both in everyday life and in stressful situations, as well as attitudes towards eating. That is, eating behaviour includes attitudes, habits, emotions related to food and are individual to each person [2-3].

There is no generally accepted classification of EB violations today. Some researchers propose to identify three conditional types of eating disorders: restrictive type of eating behaviour (EB), emotional type of EB and external type of EB [4-6].

Restrictive types of eating behaviour are excessive food self-restrictions and unsystematic diets. Periods of restrictive type of eating behaviour are replaced by periods of overeating with a new intensive weight gain. These periods lead to emotional instability - dietary depression [7-10].

Emotional type of eating behaviour - hyperphagic reaction to stress, emotional overeating. With this behaviour, the stimulus for food intake is not hunger, but emotional discomfort; food in response to stress, depression; night eating syndrome; morning anorexia; evening and night meals; insomnia; compulsive type of eating behaviour; recurrent episodes of overeating; a clear state of distress due to the presence of such episodes [11-12].

The external type of eating behaviour is manifested by an increased human response not to internal, homeostatic stimuli to eating, but to external ones. In this type of eating behaviour, the availability of products is crucial; hyperactivity to food stimuli: appearance of food, smell, taste; food for the company; frequent snacks. Unadjusted strict diet leads to: dietary depression, exacerbation of emotional instability, self-doubt, refusal to continue to follow a rational type of diet, loss of cell mass instead of fat, decreased basal metabolism and subsequent weight gain [13].

In addition to exogenous factors, the type of eating behaviour of overweight and obese people is greatly influenced by gender and age. The difference in the intensity of metabolism, endocrine and neuropsychological backgrounds, the peculiarities of the constitution, among obese people of different ages and genders, necessitates the need to take into account the above factors at the stage of corrective therapy to obtain lasting positive results in a shorter period of treatment. Of all the questionnaires on the detection of EB disorders, the simplest, most convenient and fastest to use is the DEBQ questionnaire (Netherlands). 
Thus, eating disorders can be considered as a leading factor in the development of overweight and obesity, and corrective therapy must take into account the gender and age of patients.

\section{THE AIM}

Identify the types of eating behaviour in overweight and obesity depending on gender and age.

\section{MATERIAL AND METHODS}

A survey of 210 people (men -105, women -105) was conducted on the basis of the University Clinic of Petro Mohyla National University and the TMO polyclinic of the Regional Department of the Ministry of Internal Affairs in Mykolaiv region. The age of women ranged from 19 to 60 years, the average age was $41.5 \pm 11.2$ years. The age of men ranged from 22 to 60 years, the average age was $42.3 \pm 12.3$ years. All patients were determined anthropometric data (height, weight, abdominal circumference, hip circumference), calculated body mass index (BMI), physiological parameters (blood pressure, heart rate, $\mathrm{BP}$ ).

The examined patients were divided into two clinical groups: group I - 70 people (women - 35, men - 35) with overweight. BMI of persons of the I group from $25.8 \mathrm{~kg} / \mathrm{m}^{2}$ to $29,3 \mathrm{~kg} / \mathrm{m}^{2}\left(\mathrm{BMT}_{\text {mid }}=27.5 \pm 1,31 \mathrm{~kg} / \mathrm{m}^{2}\right)$; Group II - 72 people with obesity of the I degree (women -36, men - 36). Body mass index of persons of group II from 30.0 $\mathrm{kg} / \mathrm{m}^{2}$ to $33.9 \mathrm{~kg} / \mathrm{m}^{2}\left(B M I=31.74 \pm 1.03 \mathrm{~kg} / \mathrm{m}^{2}\right)$. The control group consisted of 70 people (women -35 , men - 35) with normal weight. Body mass index from $19.8 \mathrm{~kg}$ $/ \mathrm{m}^{2}$ to $23.8 \mathrm{~kg} / \mathrm{m}^{2}\left(\mathrm{BMI}=22.4 \pm 1.43 \mathrm{~kg} / \mathrm{m}^{2}\right)$. To take into account the age characteristics of patients, in each of the groups separately studied the features of EB in women and men under 45 years and after 45 years, respectively. The following anthropometric indicators were recorded in the control group: height of males from $168 \mathrm{~cm}$ to $180 \mathrm{~cm}$ (average height $=174 \pm 6.03 \mathrm{~cm}$ ), weight from $65 \mathrm{~kg}$ to 80 $\mathrm{kg}$ (average weight $=72.5 \pm 4.21 \mathrm{~kg}$ ), waist circumference of men from $76 \mathrm{~cm}$ to $88 \mathrm{~cm}$ (average waist circumference $=$ $82 \pm 3.20 \mathrm{~cm}$ ), hip circumference from $94 \mathrm{~cm}$ to $96 \mathrm{~cm}$ (average hip circumference $=95 \pm 1.0 \mathrm{~cm}$ ), waist / thigh index from 0,82 to 0,84 (average index of a waist / hips = $0,83 \pm 0,01)$. Physiological parameters in men of the control group: blood pressure (BP) from $120 / 65 \mathrm{~mm} \mathrm{Hg}$. up to $130 / 75 \mathrm{~mm} \mathrm{Hg}\left(\mathrm{BP}_{\text {mid. }}=125 / 75 \pm 10 \mathrm{~mm} \mathrm{Hg}\right)$, heart rate (HR) from 65 to 75 beats per minute (heart rate $=70 \pm$ 2.0 beats per minute), respiratory rate (RR) from 16 to 18 respiratory movements per minute $\left(\mathrm{RR}_{\text {mid. }}=17 \pm 1.0\right.$ respiratory movements per minute).

Anthropometric indicators among women of the control group: height of females from $155 \mathrm{~cm}$ to $170 \mathrm{~cm}$ (average height $=162.5 \pm 3.03 \mathrm{~cm}$ ), weight from $55 \mathrm{~kg}$ to $70 \mathrm{~kg}$ (average weight $=62.5 \pm 5.21 \mathrm{~kg}$ ), waist circumference of women from $60 \mathrm{~cm}$ to $75 \mathrm{~cm}$ (average waist circumference $=$ $67.5 \pm 2.20 \mathrm{~cm}$ ), hip circumference from $86 \mathrm{~cm}$ to $90 \mathrm{~cm}$ (average hip circumference $=88.0 \pm 2.2 \mathrm{~cm}$ ), waist index / thighs from 0.75 to 0.80 (average waist / thigh index $=$ $0.76 \pm 0.04)$. Physiological parameters in women of the control group: blood pressure (BP) from 110/65 $\mathrm{mm} \mathrm{Hg}$. up to $130 / 75 \mathrm{~mm} \mathrm{Hg}\left(\mathrm{BP}_{\text {mid. }}=120 / 70 \pm 10 \mathrm{~mm} \mathrm{Hg}\right)$, heart rate (HR) from 64 to 74 beats per minute (heart rate $=69 \pm 4.0$ beats per minute), respiratory rate (RR) from 16 to 18 respiratory movements per minute $\left(R_{\text {mid. }}=17 \pm 3.1\right.$ respiratory movements per minute).

Anthropometric indicators in group I among men: height from $167 \mathrm{~cm}$ to $179 \mathrm{~cm}$ (average height $=173 \pm$ $5.03 \mathrm{~cm}$ ), weight from $75 \mathrm{~kg}$ to $89 \mathrm{~kg}$ (average weight = $82.5 \pm 4.21 \mathrm{~kg}$ ), waist circumference of men from $80 \mathrm{~cm}$ to $88 \mathrm{~cm}$ (average waist circumference $=84 \pm 4.01 \mathrm{~cm}$ ), thigh circumference from $98 \mathrm{~cm}$ to $101 \mathrm{~cm}$ (average hip circumference $=99.5 \pm 1.0 \mathrm{~cm}$ ), waist / thigh index from 0,90 to 0,95 (average waist / thigh index $=0.92 \pm 0.01$ ). Physiological parameters in men of group I: blood pressure (BP) from $130 / 75 \mathrm{~mm} \mathrm{Hg}$. up to $140 / 80 \mathrm{~mm} \mathrm{Hg}\left(\mathrm{BP}_{\text {mid }}=\right.$ $135 / 80 \pm 10 \mathrm{~mm} \mathrm{Hg}$ ), heart rate (HR) from 69 to 82 beats per minute $\left(\mathrm{HR}_{\text {mid }}=75 \pm 5.2\right.$ beats per minute), respiratory rate (RR) from 17 to 19 respiratory movements per minute $(R R=18 \pm 1.02$ respiratory movements per minute). Anthropometric indicators among women of the I group: height of females from $157 \mathrm{~cm}$ to $171 \mathrm{~cm}$ (average height = $163.5 \pm 2.03 \mathrm{~cm}$ ), weight from $70 \mathrm{~kg}$ to $83 \mathrm{~kg}$ (average weight $=76.5 \pm 5.21 \mathrm{~kg}$ ), waist circumference of women from $70 \mathrm{~cm}$ to $85 \mathrm{~cm}$ (average waist circumference $=77.5$ $\pm 2.30 \mathrm{~cm}$ ), hip circumference from $90 \mathrm{~cm}$ to $96 \mathrm{~cm}$ (average hip circumference $=93.0 \pm 2.2 \mathrm{~cm}$ ), waist index / thighs from 0.85 to 0.90 (average waist / thigh index $=$ $0.87 \pm 0.04)$. Physiological parameters in women of group I: blood pressure (BP) from $120 / 75 \mathrm{~mm} \mathrm{Hg}$. up to $140 / 90$ $\mathrm{mm} \mathrm{Hg}\left(\mathrm{BP}_{\text {mid }}=130 / 82 \pm 10 \mathrm{~mm} \mathrm{Hg}\right)$, heart rate $(\mathrm{HR})$ from 70 to 79 beats per minute (heart rate $=74.5 \pm 5$ beats per minute), respiratory rate (RR) from 18 to 20 respiratory movements per minute $\left(\mathrm{RR}_{\text {mid. }}=19 \pm 1.0\right.$ respiratory movements per minute).

Anthropometric indicators of group II among men: height from $168 \mathrm{~cm}$ to $180 \mathrm{~cm}$ (average height $=174 \pm$ $6.03 \mathrm{~cm}$ ), weight from $80 \mathrm{~kg}$ to $110 \mathrm{~kg}$ (average weight = $95 \pm 5.21 \mathrm{~kg}$ ), waist circumference of men from $80 \mathrm{~cm}$ up to $88 \mathrm{~cm}$ (average waist circumference $=84 \pm 4.01$ $\mathrm{cm}$ ), hip circumference from $99 \mathrm{~cm}$ to $105 \mathrm{~cm}$ (average hip circumference $=100.5 \pm 1.1 \mathrm{~cm}$ ), waist $/$ hip index from 0.99 to 1.02 ( average waist / thigh index $=1.01 \pm$ 0.01). Physiological parameters in men of group II: blood pressure (BP) from $135 / 75 \mathrm{~mm} \mathrm{Hg}$. up to $160 / 90 \mathrm{~mm} \mathrm{Hg}$ $\left(\mathrm{BP}_{\text {mid. }}=148 / 85 \pm 10 \mathrm{~mm} \mathrm{Hg}\right)$, heart rate $(\mathrm{HR})$ from 70 to 82 beats per minute $\left(\mathrm{HR}_{\text {mid. }}=76 \pm 6.2\right.$ beats per minute), respiratory rate (RR) from 17 to 19 respiratory movements per minute $(\mathrm{RR}=18 \pm 1.02$ respiratory movements per minute). Anthropometric indicators among women of the II group: height of females from $155 \mathrm{~cm}$ to $172 \mathrm{~cm}$ (average height $=164.5 \pm 3.03 \mathrm{~cm}$ ), weight from $80 \mathrm{~kg}$ to $93 \mathrm{~kg}$ (average weight $=86.5 \pm 6.21 \mathrm{~kg}$ ), waist circumference of women from $84 \mathrm{~cm}$ to $92 \mathrm{~cm}$ (average waist circumference $=88.5 \pm 2.10 \mathrm{~cm}$ ), hip circumference from $94 \mathrm{~cm}$ to $100 \mathrm{~cm}$ (average hip circumference $=97.0 \pm 2.2$ 
$\mathrm{cm}$ ), waist index / thighs from 0.89 to 0.95 (average waist / thigh index $=0.92 \pm 0.03$ ). Physiological parameters in women of group II: blood pressure (BP) from 135/90 mm Hg. up to $170 / 95 \mathrm{~mm} \mathrm{Hg}\left(\mathrm{BP}_{\text {mid. }}=155 / 92 \pm 10 \mathrm{~mm} \mathrm{Hg}\right)$, heart rate (HR) from 72 to 79 beats per minute $\left(\mathrm{HR}_{\text {mid. }}=\right.$ $75.5 \pm 5$ beats per minute), respiratory rate (RR) from 18 to 20 respiratory movements per minute $\left(R_{\text {mid. }}=19 \pm 1.0\right.$ respiratory movements per minute).

EB disorders were assessed using the DEBQ questionnaire (Netherlands) adapted to the purpose of the study. The questionnaire included 33 questions to identify violations of EB, each answer was evaluated at 5 points, so if the answer: never -1 point, rarely -2 point, sometimes -3 point, often -4 point, very often -5 point. The only exception was question 31 (where the scores were distributed in reverse order: 5 point - never, 4 point - rarely, 3 point - sometimes, 2 point - often, 1 point- very often). The questionnaire was supplemented and expanded with additional questions about the presence of heredity in the families of respondents, the frequency of meals, people's use of hormonal drugs, as well as in the first block of our questionnaire - emphasis on gender, age, occupation and ethnicity. The obtained results of answers to the first 10 questions (respectively 1-10 questions according to the questionnaire corresponding to the limiting type of EB) were added and divided by 10 . The result obtained for the first 10 questions, we compared with the normative value - 2.4 (for the restrictive type of EB) and analyzed. The second block of answers to questions 11 to 23 questions (respectively 11-23 questions according to the questionnaire, which corresponds to the emotional type of EB), were first added and then divided by 13 . The normative indicator for the emotional type of EB was - 1.8. The third block of answers to questions 24 to 33 , which is responsible for the external type of EB, similar to the first block, the sum of points obtained for each answer was divided by 10 and analyzed. The normative indicator of this block, respectively, is 2.7 (for the external type of EB).

The study was conducted in accordance with the basic bioethical norms of the Helsinki Declaration of the World Medical Association on ethical principles of scientific and medical research, as amended (2000, as amended in 2008), the Universal Declaration on Bioethics and Human Rights (1997), the Council of Europe Convention on Human Rights and Biomedicine 1997). All participants were informed about the goals, organization, methods of the study and signed an informed consent to participate in it, and all measures were taken to ensure the anonymity of patients.

Statistical processing of research results was carried out by methods of variation statistics, implemented by the standard application package SPSS 13.0 for Windows. Descriptive statistics were used for statistical data analysis; comparison of the average values of the variables was carried out using parametric methods (Student's t-test) with a normal distribution of these features, expressed in the interval scale. Fisher's exact test was used to compare the particle distribution of two or more variables. The difference was considered significant if the achieved level of significance ( $\mathrm{p}$-value) was below 0.05 .

\section{RESULTS}

The study found that the types of eating behaviour of patients had a certain dependence on body mass index. Thus, among the control group $(\mathrm{n}=70)$ with $\mathrm{BMI}_{\text {mid. }}=$ $22.4 \pm 1.43 \mathrm{~kg} / \mathrm{m} 2$, there was the following of types of eating disorders: a healthy type of $\mathrm{EB}$ - was observed in 43 (61.4\%) people, restrictive type of $\mathrm{EB}$ - in 9 (12.8\%) people; emotional type of EB - in $5(7.1 \%)$ people; external type of $\mathrm{EB}-$ in $13(18.7 \%)$ people. In patients of group I $(\mathrm{n}=70)$ with $\mathrm{BMI}=27.5 \pm 1.31 \mathrm{~kg} / \mathrm{m}^{2}$, respectively: a healthy type of EB was observed in $8(11.4 \%)$ people, a restrictive type of EB - in 31 (44.3\%) persons; emotional type of EB - in 4 (5.7\%) people; external type of $\mathrm{EB}$ - in 27 (38.6\%) people. Distribution of types of EB in group II $(\mathrm{n}=92)$ with $\mathrm{BMI}=$ $31.74 \pm 1.03 \mathrm{~kg} / \mathrm{m}^{2}$ : healthy type of eating behaviour (EB) was observed in $4(5.5 \%)$ people, restrictive type of $\mathrm{EB}-$ in $34(48.5 \%)$ persons; emotional type of EB - in $5(7.1 \%)$ people; external type of EB - in 29 (38.9\%) people.

\section{DISCUSSION}

That is, in all clinical groups the leading disorder was EB by restrictive type. Among patients of group I: disorder of the restrictive type of $\mathrm{EB}$ was recorded 3,44 times more often than in the control group $(\mathrm{D}=0.161$, $\mathrm{p}$-value $=0.046$ $<0.05)$, disorder of external type of EB was recorded 2.07 times more often than in the control group $(D=0.310$, $\mathrm{p}$-value $=0.001<0.05)$, and a healthy type of EB in overweight people was recorded 5.38 times less often than in persons with normal weight $(\mathrm{D}=13.561, \mathrm{p}=0.002<0.05)$. Thus, the comparison of eating disorders in overweight and normal weight patients showed that with increasing weight of patients, the percentage of eating disorders increases, mainly due to the dominance of the restrictive type of EB.

Among the patients of group II restrictive type EB disorder was also leading and was recorded 3.78 times more often than in the control group $(\mathrm{D}=0.153$, $\mathrm{p}$-value $=$ $0.061<0.05)$, the disorder by external type of EB in obese individuals was observed 2.23 times more often than in controls $(\mathrm{D}=0.281$, $\mathrm{p}$-value $=0.001<0.05)$, and a healthy type of EB in obese individuals, was recorded 10.75 times less often than in normal weight individuals $(\mathrm{D}=21.043, \mathrm{p}=$ $0.022<0.05)$. That is, obese patients maintained a similar trend as overweight patients: with increasing body mass index - an increase in the percentage of eating disorders, especially due to restrictive disorders of EB. (Table I).

A relationship between body mass index and type of eating behaviour was found among patients in the control group $\left(\mathrm{x}^{2}=15.592\right.$, $\mathrm{p}$-value $\left.=0.001<0.05\right)$, among patients of the first group $\left(\mathrm{x}^{2}=41.179, \mathrm{p}\right.$-value $\left.=0.001<0.05\right)$ and among patients of the second group $\left(\mathrm{x}^{2}=11.005\right.$, $\mathrm{p}$-value $=$ $0,011<0.05$ ). (Table II)

Analysis of the gender characteristics of EB disorders in overweight and obese people found a relationship between the type of EB disorder and the sex of the subjects.

In group I, the restrictive type of EB among women occurred 1.7 times more often than in men $(D=0.852, p=$ 0.001). Emotional type of EB in women and men was same 
Table I. Types of eating behaviour among patients of different clinical groups, depending on BMI ( $\mathrm{kg} / \mathrm{m} 2)$

\begin{tabular}{|c|c|c|c|c|c|c|c|c|c|c|c|c|}
\hline \multirow[t]{2}{*}{$\begin{array}{l}\text { Types of eating } \\
\text { behaviour } \\
\text { (EB) }\end{array}$} & \multicolumn{2}{|c|}{$\begin{array}{l}\text { Control group, } \\
\text { BMI }_{\text {mid. }}=22,4 \\
\pm 1,43 \mathrm{~kg} / \mathrm{m}^{2} \\
(\mathrm{n}=70)\end{array}$} & \multicolumn{2}{|c|}{$\begin{array}{c}\text { I group, } \\
\text { BMI }{ }_{\text {mid. }}=27,5 \\
\pm 1,31 \mathrm{~kg} / \mathrm{m}^{2} \\
(\mathrm{n}=70)\end{array}$} & \multicolumn{2}{|c|}{$\begin{array}{l}\text { The difference } \\
\text { between the } \\
\text { control and } \\
\text { I groups }\end{array}$} & \multicolumn{2}{|c|}{$\begin{array}{c}\text { Il group } \\
\mathrm{BMI}_{\text {mid }}=31,74 \\
\pm 1,03 \mathrm{~kg} / \mathrm{m}^{2} \\
(\mathrm{n}=72)\end{array}$} & \multicolumn{2}{|c|}{$\begin{array}{l}\text { The difference } \\
\text { between the } \\
\text { control and } \\
\text { II groups }\end{array}$} & \multicolumn{2}{|c|}{$\begin{array}{c}\text { The difference } \\
\text { between I } \\
\text { and II groups }\end{array}$} \\
\hline & $\mathbf{n}$ & $\%$ & $\mathbf{n}$ & $\%$ & D & P-value & $\mathbf{n}$ & $\%$ & D & P-value & D & P-value \\
\hline Healthy type of EB & 43 & $61,4 \%$ & 8 & $11,4 \%$ & 13.561 & 0.002 & 4 & $5,5 \%$ & 21.043 & 0.022 & 0.501 & 0.037 \\
\hline Restrictive type of EB & 9 & $12,8 \%$ & 31 & $44,3 \%$ & 0.161 & 0.046 & 34 & $48,5 \%$ & 0.153 & 0.061 & 0.902 & 0.051 \\
\hline Emotional type of EB & 5 & $7,1 \%$ & 4 & $5,7 \%$ & 0.532 & 0.40 & 5 & $7,1 \%$ & 0.480 & 0.28 & 1.910 & 1.000 \\
\hline External type of EB & 13 & $18,7 \%$ & 27 & $38,6 \%$ & 0.310 & 0.001 & 29 & $38,9 \%$ & 0.281 & 0.001 & 0.942 & 0.041 \\
\hline
\end{tabular}

Table II. Relationship between eating behaviour and BMI $(\mathrm{kg} / \mathrm{m} 2)$ in patients of different clinical groups

\begin{tabular}{|c|c|c|c|c|c|c|c|c|c|c|c|c|}
\hline \multirow{2}{*}{$\begin{array}{l}\text { Types of eating } \\
\text { behaviour } \\
\text { (EB) }\end{array}$} & \multicolumn{4}{|c|}{$\begin{array}{c}\text { Control group, } \\
\text { BMI }_{\text {mid. }}=22,4 \pm 1,43 \mathrm{~kg} / \mathrm{m}^{2} \\
(n=70)\end{array}$} & \multicolumn{4}{|c|}{$\begin{array}{c}\text { I group, } \\
\text { BMI }_{\text {mid. }}=27,5 \pm 1,31 \mathrm{~kg} / \mathrm{m}^{2} \\
(n=70)\end{array}$} & \multicolumn{4}{|c|}{$\begin{array}{c}\text { II group, } \\
B M I_{\text {mid }}=31,74 \pm 1,03 \mathrm{~kg} / \mathrm{m}^{2} \\
(n=72)\end{array}$} \\
\hline & $\mathbf{n}$ & $\%$ & $x^{2}$ & p-value & $n$ & $\%$ & $x^{2}$ & p-value & $n$ & $\%$ & $x^{2}$ & p-value \\
\hline Healthy type of EB & 43 & $61,4 \%$ & \multirow{4}{*}{15,592} & \multirow{4}{*}{0,001} & 8 & $11,5 \%$ & \multirow{4}{*}{41,179} & \multirow{4}{*}{0,001} & 4 & $5,5 \%$ & \multirow{4}{*}{11,005} & \multirow{4}{*}{0,011} \\
\hline Restrictive type of EB & 9 & $12,8 \%$ & & & 31 & $44,2 \%$ & & & 34 & $48,5 \%$ & & \\
\hline Emotional type of EB & 5 & $7,1 \%$ & & & 4 & $5,8 \%$ & & & 5 & $7,1 \%$ & & \\
\hline External type of EB & 13 & $18,7 \%$ & & & 27 & $38,5 \%$ & & & 29 & $38,9 \%$ & & \\
\hline
\end{tabular}

range $(\mathrm{D}=1.261, \mathrm{p}=1.003)$. The external type of $\mathrm{EB}$ was 1.3 times greater in men than in women $(\mathrm{D}=0.731, \mathrm{p}=$ $0.005)$. A healthy type of $\mathrm{EB}$ in overweight men and women was same range $(\mathrm{D}=1.421, \mathrm{p}=1.003)$. Thus, among overweight men, the predominance of EB disorders by external type was recorded, and in women - the restrictive type of EB was more common.

In group II, the restrictive type of $\mathrm{EB}$ among women was observed 1.3 times more often than in men $(\mathrm{D}=1.382, \mathrm{p}=$ 0.005). Gender differences in the frequency of detection of the emotional type of EB were not found $(\mathrm{D}=1.001, \mathrm{p}=$ $0,001)$. The external type of EB in group II was 1.13 times higher in men than in women $(\mathrm{D}=0.861, \mathrm{p}=0.008)$. Gender differences in the frequency of detection of the health type of EB were not found $(\mathrm{D}=1.481, \mathrm{p}=0.064)$. Among obese patients, as well as among overweight patients, the predominance of EB disorders by external type in males and the dominance of the restrictive type of EB in female patients were recorded. (Table III)

In the analysis of age-related features of EB disorders, it was found that the restrictive type of EB prevailed in young people, and the external type was leading among patients after 45 years.

In men of group I after 45 years, a healthy type of EB occurred 8.09 times more often than in men under 45 years $(\mathrm{D}=0.11, \mathrm{p}$-value $=0.03<0.05)$. This feature suggests that with age, men are more demanding when choosing food and more labile to modify their eating behaviour and lifestyle. In women of group I, a healthy type of EB was observed 8.09 times less often than in men of group I of the same age category $(D=0.11$, p-value $=$ $0.03<0.05)$. This fact is probably due to the psychological characteristics of females, namely: a greater tendency to strict diets, a higher percentage of dissatisfaction with their own forms, even with a normal body mass index, all this encourages females to the ability to limit themselves in food for longer, and as a consequence of the formation of stress, disruption of diets and weight gain even more than before the diet. (Table IV).

Data from the analysis of the world literature show the great interest of scientists around the world, the problem of growth and correction of overweight among obese people $[9,12]$. At the same time, the vast majority of authors focus primarily on the modification of eating behaviour as a key factor in the development of overweight and obesity [10]. Of course, the refusal to eat refined foods, snacks for company, night consumption significantly improves the gastrointestinal tract, cardiovascular system of obese and overweight people [5]. At the same time, in our opinion, and in the opinion of some researchers $[1,8]$, the correction of eating disorders in obese people must be carried out taking into account the sex and age of patients, to obtain positive results for a shorter course of treatment and for a longer period of rehabilitation.

\section{CONCLUSIONS}

The generalization of the results obtained in the study allowed us to formulate the following conclusions:

1. Eating disorders are one of the leading factors in the development of overweight and obesity: in overweight patients a healthy type of eating behaviour was recorded 5.38 times less often than in people with normal weight $(\mathrm{D}=13.561, \mathrm{p}=0.002<0.05)$, and in obese patients 10.45 times less often than in normal weight individuals $(\mathrm{D}=21.043, \mathrm{p}=0.022<0.05)$. 
Table III. Gender features of eating behaviour in overweight and obese people

\begin{tabular}{|c|c|c|c|c|c|c|c|c|c|c|c|c|}
\hline \multirow[t]{2}{*}{$\begin{array}{l}\text { Types of eating } \\
\text { behaviour } \\
\text { (EB) }\end{array}$} & \multicolumn{2}{|c|}{$\begin{array}{c}\text { I group, } \\
\text { women, } \\
\text { Age }_{\text {mid. }}= \\
42,5 \pm 12,2 \\
\text { years } \\
(n=35)\end{array}$} & \multicolumn{2}{|c|}{$\begin{array}{l}\text { I group, } \\
\text { men, } \\
\text { Age }_{\text {mid.. }}= \\
43,3 \pm 12,4 \\
\text { years } \\
(n=35)\end{array}$} & \multicolumn{2}{|c|}{$\begin{array}{c}\text { Difference } \\
\text { types of EB } \\
\text { in patients } \\
\text { group I, } \\
\text { depending } \\
\text { on gender }\end{array}$} & \multicolumn{2}{|c|}{$\begin{array}{c}\text { Il group, } \\
\text { women, } \\
\text { Age }_{\text {mid. }}= \\
41,5 \pm 12,2 \\
\text { years } \\
(n=36)\end{array}$} & \multicolumn{2}{|c|}{$\begin{array}{l}\text { II group, } \\
\text { men, } \\
\text { Age }_{\text {mid. }}= \\
43,0 \pm 12,4 \\
\text { years } \\
(n=36)\end{array}$} & \multicolumn{2}{|c|}{$\begin{array}{l}\text { Difference } \\
\text { types of EB } \\
\text { in patients } \\
\text { group II, } \\
\text { depending } \\
\text { on gender }\end{array}$} \\
\hline & $\mathbf{n}$ & $\%$ & $\mathbf{n}$ & $\%$ & D & P-value & $\mathbf{n}$ & $\%$ & $\mathbf{n}$ & $\%$ & D & p-value \\
\hline Healthy type of EB & 4 & $5,8 \%$ & 4 & $5,7 \%$ & 1.421 & 1.003 & 2 & $2,7 \%$ & 2 & $2,8 \%$ & 1.481 & 0.064 \\
\hline Restrictive type of EB & 17 & $24,2 \%$ & 14 & $20,0 \%$ & 0.852 & 0.001 & 19 & $27,1 \%$ & 15 & $21,4 \%$ & 0.382 & 0.005 \\
\hline Emotional type of EB & 2 & $2,9 \%$ & 2 & $2,9 \%$ & 1.001 & 1.003 & 3 & $4,3 \%$ & 2 & $2,8 \%$ & 1.002 & 0.001 \\
\hline External type of EB & 12 & $17,1 \%$ & 15 & $21,4 \%$ & 0.731 & 0.005 & 12 & $16,7 \%$ & 17 & $22,2 \%$ & 0.861 & 0.008 \\
\hline
\end{tabular}

Table IV. Age features of eating behaviour in overweight people

\begin{tabular}{|c|c|c|c|c|c|c|c|c|c|c|c|c|c|c|c|c|}
\hline \multirow[t]{2}{*}{$\begin{array}{l}\text { Types of } \\
\text { eating } \\
\text { behaviour } \\
\text { (EB) }\end{array}$} & \multicolumn{2}{|c|}{$\begin{array}{l}\text { I group, } \\
\text { women } \\
\text { under } 45 \\
\text { years, } \\
(n=19)\end{array}$} & \multicolumn{2}{|c|}{$\begin{array}{l}\text { I group, } \\
\text { women } \\
\text { over } 45 \\
\text { years, } \\
(n=16)\end{array}$} & \multicolumn{2}{|c|}{$\begin{array}{c}\text { Difference } \\
\text { types of EB } \\
\text { in women of } \\
\text { group I, } \\
\text { depending on } \\
\text { age }\end{array}$} & \multicolumn{2}{|c|}{$\begin{array}{l}\text { I group, } \\
\text { men under } \\
45 \text { years, } \\
(n=17)\end{array}$} & \multicolumn{2}{|c|}{$\begin{array}{l}\text { I group, } \\
\text { men } \\
\text { over } 45 \\
\text { years } \\
(n=18)\end{array}$} & \multicolumn{2}{|c|}{$\begin{array}{l}\text { Difference } \\
\text { types of EB } \\
\text { in men } \\
\text { I group, } \\
\text { depending on } \\
\text { age }\end{array}$} & \multicolumn{2}{|c|}{$\begin{array}{l}\text { The difference } \\
\text { between the } \\
\text { types of EB } \\
\text { in women and } \\
\text { men of group I } \\
\text { under the age } \\
\text { of } 45 \text { years }\end{array}$} & \multicolumn{2}{|c|}{$\begin{array}{l}\text { The difference } \\
\text { between the } \\
\text { types of EB } \\
\text { in women and } \\
\text { men I group } \\
\text { aged after } \\
45 \text { years old }\end{array}$} \\
\hline & $n$ & $\%$ & n & $\%$ & D & P-value & $n$ & $\%$ & n & $\%$ & D & P-value & D & P-value & D & P-value \\
\hline $\begin{array}{l}\text { Healthy type } \\
\text { of EB }\end{array}$ & 3 & $4,4 \%$ & 1 & $1,4 \%$ & 3.05 & 0.62 & 1 & $1,4 \%$ & 3 & $4,3 \%$ & 0.11 & 0.03 & 3.05 & 0.62 & 0.11 & 0.03 \\
\hline $\begin{array}{c}\text { Restrictive type } \\
\text { of } E B\end{array}$ & 11 & $15,7 \%$ & 6 & $8,5 \%$ & 1.65 & 0.37 & 9 & $12,9 \%$ & 5 & $7,1 \%$ & 1.88 & 0.40 & 1.65 & 0.37 & 1.88 & 0.40 \\
\hline $\begin{array}{c}\text { Emotional type } \\
\text { of EB }\end{array}$ & 1 & $1,4 \%$ & 1 & $1,5 \%$ & 0.66 & 1.00 & 1 & $1,4 \%$ & 1 & $1,5 \%$ & 3.05 & 0.62 & 0.66 & 1.00 & 3.05 & 0.62 \\
\hline $\begin{array}{l}\text { External type } \\
\text { of } E B\end{array}$ & 4 & $5,7 \%$ & 8 & $11,4 \%$ & 0.42 & 0.24 & 6 & $8,5 \%$ & 9 & $12,9 \%$ & 1.00 & 1.00 & 0.42 & 0.24 & 1.00 & 1.00 \\
\hline
\end{tabular}

2. Overweight and obesity are most often associated with restrictive eating behaviour: 3.44 times more often in overweight people $(\mathrm{D}=0.161$, $\mathrm{p}$-value $=0.046<0.05)$, and in obese patients - disorders of the restrictive type of EB are 3.78 times more often compared to the control group $(\mathrm{D}=0.153$, $\mathrm{p}$-value $=0.061<0.05)$.

3 . The type of eating behaviour in all clinical groups, except for body mass index, was influenced by gender and age of the subjects. Thus, in overweight men after the age of 45 a healthy type of eating behaviour occurred 8.09 times more often than in men under the age of $45(\mathrm{D}=$ $0.11, \mathrm{p}$-value $=0.03<0.05)$ and in overweight women $(\mathrm{D}=0.11$, $\mathrm{p}$-value $=0.03<0.05)$.

4. The relationship between the type of eating behaviour and gender and age characteristics of patients was found and confirmed by correlation analysis in all clinical groups.

Practical significance and prospects for further research. Correction of eating disorders in obese people must be carried out taking into account the gender and age characteristics of the patient, to obtain positive results for a shorter course of treatment. Medical advice for women and young people, taking into account the prevalence of restrictive EB disorders, should be aimed at combating strict diets and periods of prolonged starvation, and for men and people over 45 - to follow a balanced and balanced diet. The duration of corrective treatment in obese women should be increased through psychotherapy.

\section{REFERENCES}

1. Dietary Flavonoid Intake Is Inversely Associated with Cardiovascular Disease Risk as Assessed by Body Mass Index and Waist Circumference among Adults in the United States. Nutrients. 2017; 9 (12): 827-9.

2. Batsis J. A. Addressing Obesity in Aging Patients. Medical Clinics of North America. 2018; 102 (1): 65-85.

3. Nadolsky K. Z. Rationale for Utilization of Obesity Pharmacotherapy in the Active Duty Population. Military Medicine. 2018.

4. Kones R. Cultural primer for cardiometabolic health: health disparities, structural factors, community, pathways to improvement, and clinical applications. Postgraduate Medicine. 2018; 132: 1-22.

5. Bray G. A. Obesity: a chronic relapsing progressive disease process. A position statement of the World Obesity Federation. Obesity Reviews. 2017: 18 (7): 715-23.

10. Longo D. L. Mechanisms, Pathophysiology, and Management of Obesity. New England Journal of Medicine. 2017; 376 (3): 254-66.

6. Wurtman J. Depression can beget obesity can beget depression. Psychiatry. 2017; 76: 1619-21.

7. Silva I. Importance of emotional regulation in obesity and weight loss treatment. Fractal. Rev. Psicol. 2017; 27 (3): 286-90.

8. Ursavas A., Ilcol Y.0., Nalci N. et al. Ghrelin, leptin, adiponectin, and resistin levels in sleep apnea syndrome: Role of obesity. Ege Ann. Thorac. Med. 2017; 5 (3): 161-5.

9. Vinales K.L., Schlögl M., Piaggi P. et al. The Consistency in Macronutrient Oxidation and the Role for Epinephrine in the Response to Fasting and Overfeeding. J. Clin. Endocrinol. Metab. 2017; 102 (1): 279-89. 
10. Skrypnik D., Bogdański P., Mądry E. et al. Effects of endurance and endurance strength training on body composition and physical capacity in women with abdominal obesity. Obes. Facts. 2018; 8 (3): 182-3.

11. Dixon J. B. Fat-free mass loss generated with weight loss in overweight and obese adults: what may we expect? Diabetes, Obesity and Metabolism. 2019; 17 (1): 91-3.

12. Zhang H., Tong T.K., Qiu W. et al. Comparable effects of high-intensity interval training and prolonged continuous exercise training on abdominal visceral fat reduction in obese young women. Journal of Diabetes Research. 2017; 2 (8).

13. Ostchega Y., Hughes J. P., Terry A. et al. Abdominal obesity, body mass index, and hypertension in US adults: NHANES 2007-2010. Am. J. Hypertens. 2016; 25 (12): 1271-1278. D0I: 10.1038/ajh.2012.120.

The work is a fragment of the research project "Clinical and pathogenesis substantiation of primary and secondary prevention systems of the most socially significant chronic non-infectious diseases of the internal organs"( state registration number: 0120U101641).

\section{ORCID and contributionship:}

Liudmyla S. Kiro: 0000-0003-2146-283X A, B, C, D

Maksym Y. Zak: 0000-0002-9931-4290, F
Oleh V. Chernyshov: 0000-0001-9427-486X

Alla E. Nikolenko: 0000-0001-5523-8858

Nataliia O. Iakovenko: 0000-0002-5669-7957

\section{Conflict of interest:}

The Authors declare no conflict of interest.

\section{CORRESPONDING AUTHOR}

\section{Liudmyla S. Kiro}

Medical Institute of the Petro Mohyla Black Sea National University

13 Pavlova st., 54046 Mykolaiv, Ukraine

tel: +380936950363

e-mail: nawal08th@gmail.com

Received: 18.12 .2020

Accepted: 29.03.2021

A - Work concept and design, B - Data collection and analysis, C - Responsibility for statistical analysis,

D-Writing the article, $\mathbf{E}$-Critical review, $\mathbf{F}$ - Final approval of the article 